研 究

\title{
ワックス系潤滑剤を用いた偏析防止粉の流動性支配因子
}

\author{
上薗 聡，尾崎由紀子，小倉 邦明，中野 善文 \\ 川崎製鉄侏技術研究所, テ 260-0835 千葉市中央区川崎町 1.
}

\section{Factors determining flowability of segregation-free iron powder with lubricant containing wax}

\author{
Satoshi Uenosono, Yukiko Ozaki, Kuniaki Ogura and Yoshifumi Nakano \\ Kawasaki steel corporation, Technical Research Laboratories, 1 Kawasaki-cho Chuo-ku, Chiba 260-0835.
}

Received May 15, 1998

\section{SYNOPSIS}

Adhesive forces dominating the flowability of the segregation-free iron based powder consist of liquid bridge force, electrostatic force and van der Waals force. They were calculated and the absorption isotherm of water vapor on the segregation-free iron based powder was measured. The result indicated that the van der Waals force between binder on iron powder and lubricant powder and that between lubricant powders are main forces that determine the flowability of segregation-free iron based powder in the relative humidity less than $91 \%$.

\section{KEY WORDS}

adhesive forces, flowability, segregation-free iron based powder, liquid bridge force, electrostatic force, van der Waals force

\section{1 緒 言}

鉄系粉末治金の分野において,焼結部品の高寸法精度の要求 が強い". 一方, 粉末冶金技術は他の加工法との間で品質およ び経済性において競合しており，原料粉末に対しても高い品質 が要求される。

鉄系焼結材料の原料は, 主原料である鉄粉に銅粉, ニッケル 粉, 黒鉛粉などの合金粉と潤滑剂が混合されることが一般的で あるここの混合粉を構成する各種粉末の比重が大幅に異なるの で，焼結部品を製造するのに欠かすことができない混合，成形 工程で合金元素の偏析による品質のばらつきや, 発糜が問題と なる場合がある.

この様な問題点を解決するために，黒鉛粉等の合金粉を鉄粉 表面に有機バインダで固着させることにより，黒鉛粉の偏析を 防止した偏析防止粉が開発されている2!.

偏析防止粉は,バインダ以外に配合される潤滑剤の種類によ り,ステアリン酸亜鉛系偏析防止粉とワックス系偏析防止粉に 大別される.ワックス系偏析防止粉は，ステアリン酸覀鉛系偏 析防止粉のように脱ろう時に発生する酸化亜鉛が焼結炉に付着 する問題が無く, 焼結体表面にすすが発生しにくい利点がある が, ステアリン酸覀鉛系偏析防止粉に比べ, 流動性が悪い問題
点がある、このため，流動性に優れたワックス系偏析防止粉の 開発が望まれている.

石川らは,ワックス系偏析防止粉の剪断試験を行い, 流動度 は内部摩擦力には依存せず,付着力に依存することを明らかに $\left(た^{3)}\right.$. 付着力は, 液架橋力, 静電気力, 分子間力から成り立 つことが知られている4!

本研究では市販のワックス系偏析防止粉における液架橋力, 静電気力, 分子間力の大ききを計算し; 流動性を支配する因子 を推定した。また付着力を実際に測定し，計算結果と比較し た。

\section{2 実験方法}

市販のワックス系偏析防止粉(川崎製鉄製ワックス系クリー ンミックス，配合; Fe-0.8mass\%黑鉛粉 -0.75 mass\%潤滑剂) を

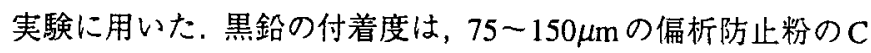
分析值と偏析防止粉全体のC分析値の比として測定した" . 粒 子の形状を観察するため, 偏析防止粉, 使用した鉄粉, 黒鉛粉, 潤滑剤の SEM観察を行った。

鉄粉の平均粒子径は篩い分けにより，その他の粉末の平均粒 径はマイクロトラック法により測定した。 
静電気力を計算するために, ブローオフ法包により, 鉄粉と $1 \mathrm{mass} \%$ 潤滑剂の混合粉および鉄粉と $0.8 \mathrm{mass} \%$ 黒鉛粉の混合 粉の帯電量を測定した. なお, 測定される帯電量は $\mathrm{C} / \mathrm{g}$ 単位 であるので, 各粉体の比表面積 $\left(\mathrm{m}^{2} / \mathrm{g}\right)$ を BET 法で実測し, Cl $\mathrm{m}^{2}$ 単位に変換した。

液架橋力を考慮すべき湿度範囲を把握するために, ワック ス系偏析防止粉の水蒸気の等温吸着線を, $25^{\circ} \mathrm{C} て ゙$ 測定した。

粉体付着力は, 福沢・木村の方法6を参考に, 堆積充填され た粉体を電子天秤上にセットし，上部から両面テープを貼付 したアルミ板を粉体表面に置きこれを徐々に垂直に上昇さ せる際の電子天秤の最大重量変化量と両面テープに付着した 粉体重量との差から求めた。 さらに, 顕微鏡観察により両面 テープに付着した粉体の個数を求め, 粒子当たりの付着力を 算出した。

\section{3 結果と考察}

3.1 ワックス采偏析防止粉の SEM 観察

ワックス系偏析防止粉の SEM 写真を Fig.1 に示す、鉄粉表 面は $10 \mu \mathrm{m}$ 程度の表面粗さを有し,凹部に図中一印で示す様に バインダ成分が $20 \mu \mathrm{m}$ 程度の大きさで固着している. 黒鉛付着 率は $80 \%$ であり，ほとんどの黒鉛粒子はこのバインダ成分に

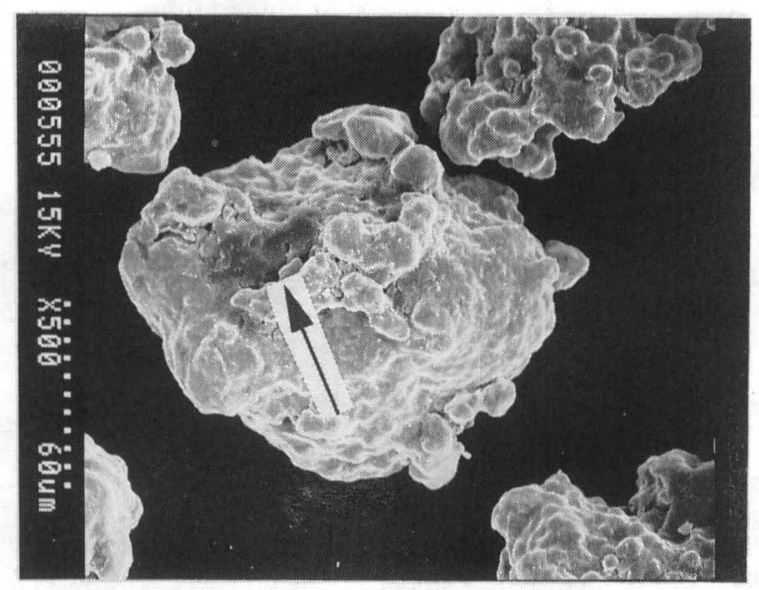

Fig.1 SEM image of the segregation-free iron based powder used.

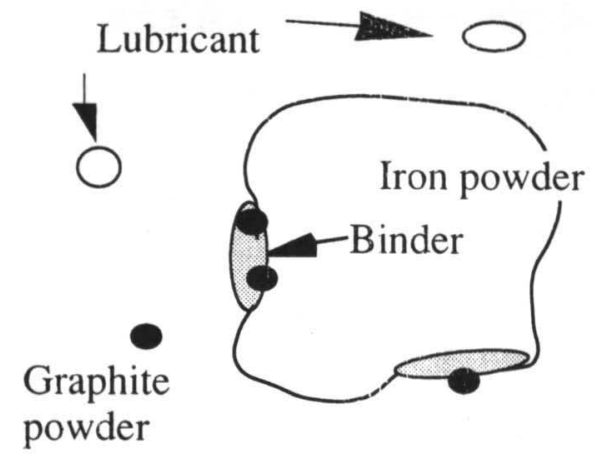

Fig.2 Schematic description of the segregation-free iron based powder used.
包み込まれるように鉄粉表面に付着していると思われる。 ま た潤滑剤は遊離粉末として添加されている。これらの観察結 果から偏析防止粉はFig.2に示すような構造を有していると考 えられる. Table 1に, 偏析防止粉を構成する粉末の平均粒径, 比表面積の測定結果と計算に用いたハマカー係数を示す”。こ こで, 潤滑剤, バインダーのハマカー係数は実測されていな い. 測定されている有機物質は, エチレングリコールとポリ スチレンであったので，本報では後者の值を用いた．

\section{2 計算結果}

\subsection{1 液架橋力}

液架橋力は粉体間の吸着水膜による表面張力に起因する力 で, 液と粒子の接触角を 0 とし, 液架橋の大きさが粒子径に 比べて十分小さいとすると, 次式で示される ${ }^{81}$.

$$
\mathrm{Fc}=-\pi \cdot \gamma \cdot \mathrm{D}
$$

ここで, $\gamma ;$ 水の表面張力 $(\mathrm{N} / \mathrm{m}), \mathrm{D} ; 2$ 粒子の換算粒径 $(\mathrm{m})$ で ある。 な抒換算粒径は次式で与えられる。

$$
\mathrm{D}=\left(\mathrm{D}_{1} \cdot \mathrm{D}_{2}\right) /\left(\mathrm{D}_{1}+\mathrm{D}_{2}\right)
$$

ここで， $\mathrm{D}_{1}, \mathrm{D}_{2}$ は各粒子の直径 $(\mathrm{m})$ である，(1) 式から，液架 橋力は粒子径に比例するので, 偏析防止粉を構成する粒子の

Table 1 Hamaker coefficients, mean particle sizes and specific surface areas of iron powder, graphite powder and lubricant powder.

\begin{tabular}{|c|c|c|c|}
\hline Material & $\begin{array}{c}\text { Hamaker } \\
\text { coefficient } \\
\left(10^{-19} \mathrm{~J}\right)\end{array}$ & $\begin{array}{c}\text { Mean } \\
\text { particle } \\
\text { size } \\
(\mu \mathrm{m})\end{array}$ & $\begin{array}{c}\text { Specific } \\
\text { surface } \\
\text { area } \\
\left(\mathrm{m}^{2} / \mathrm{g}\right)\end{array}$ \\
\hline $\begin{array}{c}\text { Iron } \\
\text { powder }\end{array}$ & 2.12 & 80 & 0.04 \\
\hline $\begin{array}{c}\text { Graphite } \\
\text { powder }\end{array}$ & 4.70 & 22 & 9.18 \\
\hline $\begin{array}{c}\text { Lubricant } \\
\text { powder }\end{array}$ & 0.70 & 20 & 7.50 \\
\hline
\end{tabular}

Table 2 Electrostatic quantity measured and electrostatic force calculated.

\begin{tabular}{|c|c|c|c|}
\hline \multicolumn{2}{|c|}{$\begin{array}{c}\text { Combination } \\
\text { of powder }\end{array}$} & $\begin{array}{c}\text { Charge } \\
(\mu \mathrm{C} / \mathrm{g})\end{array}$ & $\begin{array}{c}\text { Electrostatic force } \\
\left(10-{ }^{12} \mathrm{~N} / \text { particle }\right)\end{array}$ \\
\hline $\begin{array}{c}\text { Iron } \\
\text { powder }\end{array}$ & $\begin{array}{c}\text { Graphite } \\
\text { powder }\end{array}$ & 0.024 & 0.42 \\
\hline $\begin{array}{c}\text { Iron } \\
\text { powder }\end{array}$ & $\begin{array}{c}\text { Lubricant } \\
\text { powder }\end{array}$ & -0.084 & 2.20 \\
\hline
\end{tabular}


うちもっとも大きな鉄粉粒子間で計算した，その結果，液架 橋力は $1.8 \times 10^{-5} \mathrm{~N} /$ 個と計算された.

\section{2 .2 静電気力}

偏析防止粉を構成する鉄粉, 合金粉, 潤滑剂等の異種材料 の接触により, 静電気力が発生する. 静電気力は次式で示さ

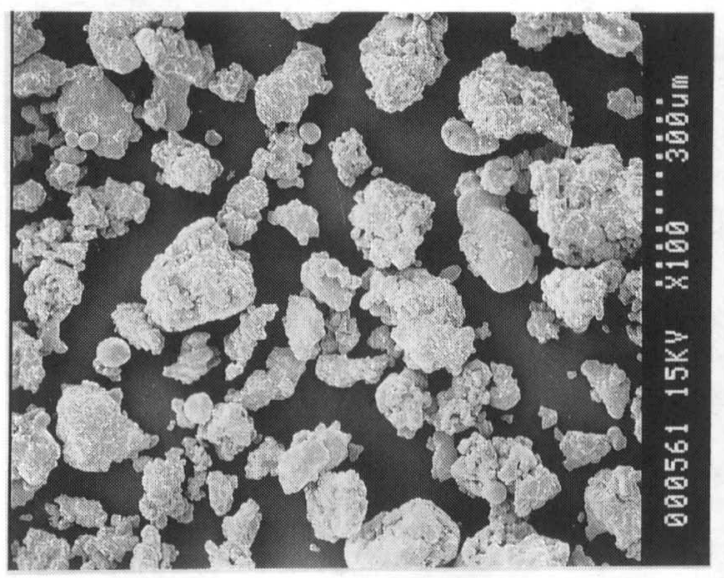

\section{Iron powder}

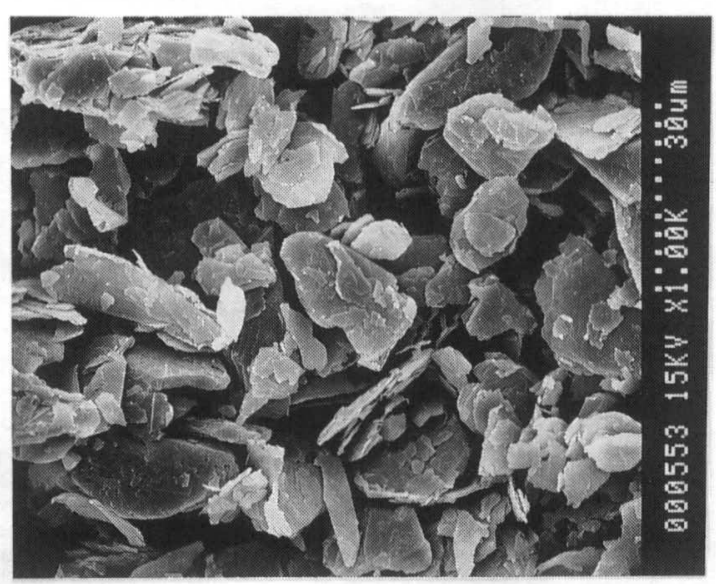

\section{Graphite powder}

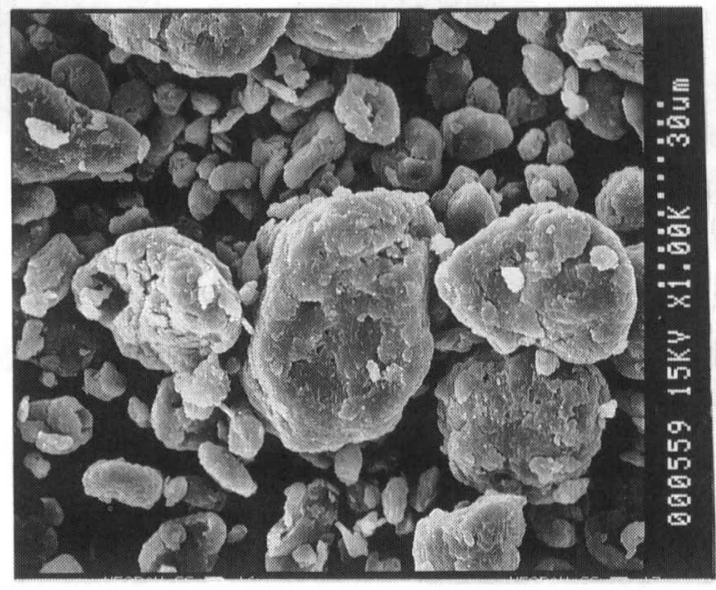

れる ${ }^{8)}$

$$
\mathrm{Fe}=\pi \cdot \sigma_{1} \cdot \sigma_{2} \cdot \mathrm{D}^{2} / \varepsilon
$$

なお， $\sigma$; 带電量 $\left(\mathrm{C} / \mathrm{m}^{2}\right), \mathrm{D} ;$ 換算粒径 $(\mathrm{m}), \varepsilon$; 真空の誘電率 $(\mathrm{F}$ $\left.\cdot \mathrm{m}^{-1}\right)$ である. ここで, $\sigma_{1}, \sigma_{2}$ は各粒子の帯電量である. たとえ
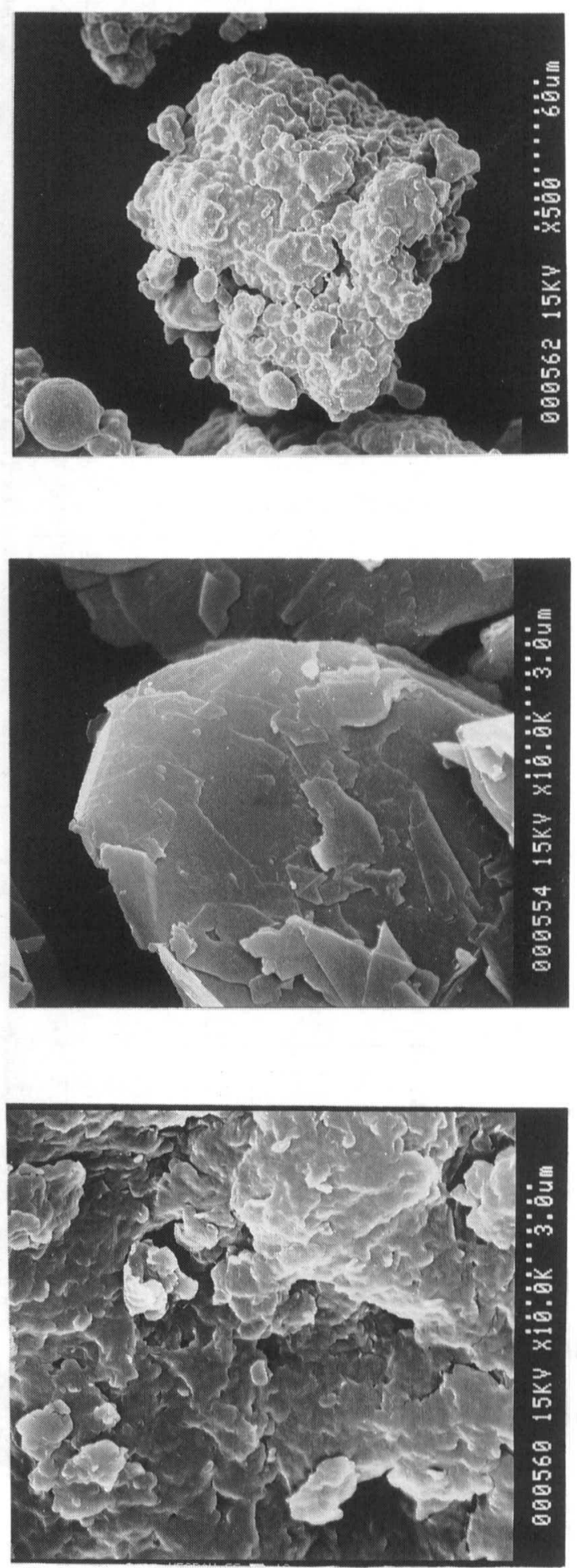

Lubricant powder

Fig.3 SEM images of iron powder, graphite powder and lubricant powder. 
ば, Table 2では，鉄粉と黒鉛粉の組み合わせにおいて，鉄粉 は $-0.024 \mu \mathrm{C} / \mathrm{g}$, 黒鉛粉は+0.024 $\mathrm{C} / \mathrm{g}$ 帯電していることを示す. ただし，バインダ成分を単独に取り出すことができなかった ので，バインダと潤滑剂間の帯電量は測定できなかった。 Table 2 に, 実測の静電気量と静電気力の計算值をまとめた. 静電気力は, 測定した粒子の種類にかかわらず, $10^{-13} \sim 10^{-12} \mathrm{~N} /$ 個の範囲である。

\section{2 .3 分子間力}

分子間力は，永久双極子能率を持つ分子同士間で生じる配 向効果による力，永久双極子能率を持つ分子が持たない分子 を分極させる時に生じる力である．2つの粒子間の分子間力 は、次式で与えられる ${ }^{8)}$.

$$
\mathrm{Fvb}=-\mathrm{A} \cdot \mathrm{D} /\left(24(\mathrm{Z}+\mathrm{b})^{2}\right)
$$

ここで, A; ハマカー係数 $(\mathrm{J}), \mathrm{D}$; 換算粒径 $(\mathrm{m}), \mathrm{Z}$; 粉体間の距 離 $(40 \mathrm{~nm}), \mathrm{b}$; 粉体の表面粗さ $(\mathrm{m})$ である. 異種粒子間のハマ カー係数，粉体の表面粗さは次式で示される.

Table 3 Van der Waals force calculated

\begin{tabular}{|c|c|c|}
\hline \multicolumn{2}{|l|}{ Combination of powder } & $\begin{array}{l}\text { Van der Waals } \\
\text { force } \\
\left(10^{-15} \mathrm{~N} / \text { particle }\right.\end{array}$ \\
\hline Iron powder & $\begin{array}{c}\text { Graphite } \\
\text { powder }\end{array}$ & 9.07 \\
\hline Iron powder & $\begin{array}{c}\text { Lubricant } \\
\text { powder }\end{array}$ & 3.25 \\
\hline
\end{tabular}

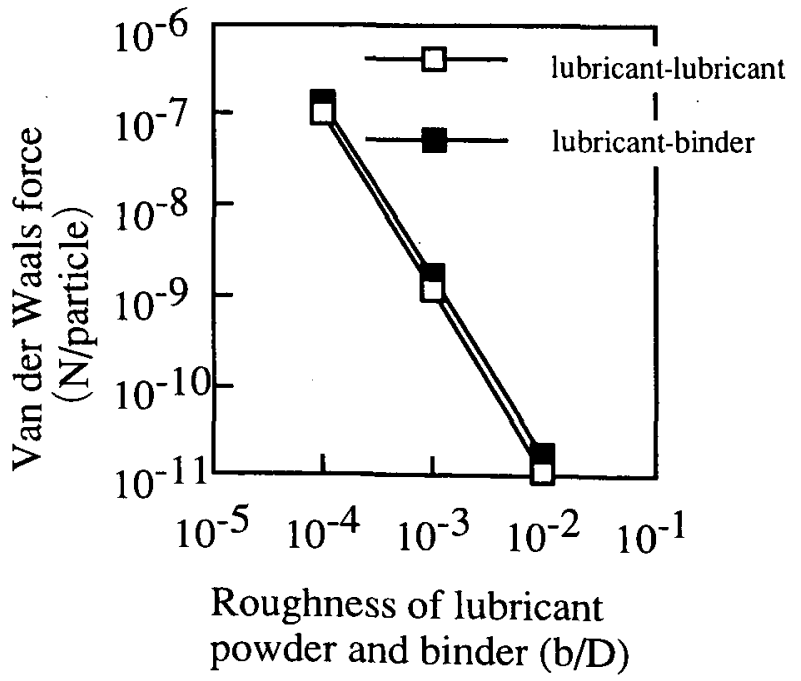

Fig.4 Effect of roughness of lubricant powder and binder on van der Waals force between lubricants and that between lubricant powder and binder on iron powder.

$$
\begin{aligned}
& A=\left(A_{1} \cdot A_{2}\right)^{0.5} \\
& b=\left(b_{1}+b_{2}\right) / 2
\end{aligned}
$$

ここで, $A_{1}, A_{2}$ は各粒子のハマカー係数， $b_{1}, b_{2}$ は各粒子の表 面粗さである.ここでは偏析防止粉を構成する金属粉，潤滑 剂の種々の組み合わせの2種の粒子間の分子間力を計算した。

Fig.3に実験に使用した粉体のSEM写真を示す。鉄粉は 10 一 $20 \mu \mathrm{m}$ 程度の一次粒子からなり, 表面粗さの大きさは $10 \mu \mathrm{m}$ 程度である．Fig.3に示すように黒鉛粉は，直径が $20 \mu \mathrm{m}$ 程度 の扁平状の粉末である，その表面は，粉砕時に生成したと思 われるへき開面であったので, 表面粗さは計算では0とした。 潤滑剂，バインダの最表面は，Fig.1,3に示すように滑らかで あり，表面粗さを表面の表面粗さと直径の比 (b/D)で 1.0 $0.01 \% の$ 範囲で計算した。

Table 3 に鉄粉と各種粒子の分子間力をまとめて示す、鉄粉 と各種粒子間の分子間力は $10^{-15} \mathrm{~N} /$ 個程度である. Fig.4にバイ ンダと潤滑剤間ならびに潤滑剤同士間の分子間力と粒子表面 の表面粗さと直径の比の関係を示す．潤滑剂およびバインダ の表面が滑らかなほど分子間力は大きくなり，その大きさは $10^{-11} \sim 10^{-7} \mathrm{~N} /$ 個である。これらの計算結果から，最大の分子間 カはバインダと潤滑剤間ならびに潤滑剤同士間に作用すると 考えられる。

\section{3 流動性を支配する力}

3.2 節での計算結果から, 液架橋力 $>$ 分子間力 $>$ 静電気力の 順に小さくなることがわかった．液架橋力は粒子間に水分子 が多䉕吸着した状態で発生すると考えられる. Fig.5にワック 㐿偏析防止粉の水蒸気の等温吸着線を示す。相対湿度 $91 \%$ までは水分子は単分子吸着し，相対湿度 $91 \%$ 以上では多層吸 着である，この結果から，通常の粉末治金の混合，成形での 作業条件下では，液架橋力は無視できると考えられる。した がって，バインダと潤滑剤間ならびに潤滑㓮同士間の分子間 力が主たる流動性支配因子と考えられる.

また,ワックス采偏析防止粉の付着力の測定結果は $10.9 \times$
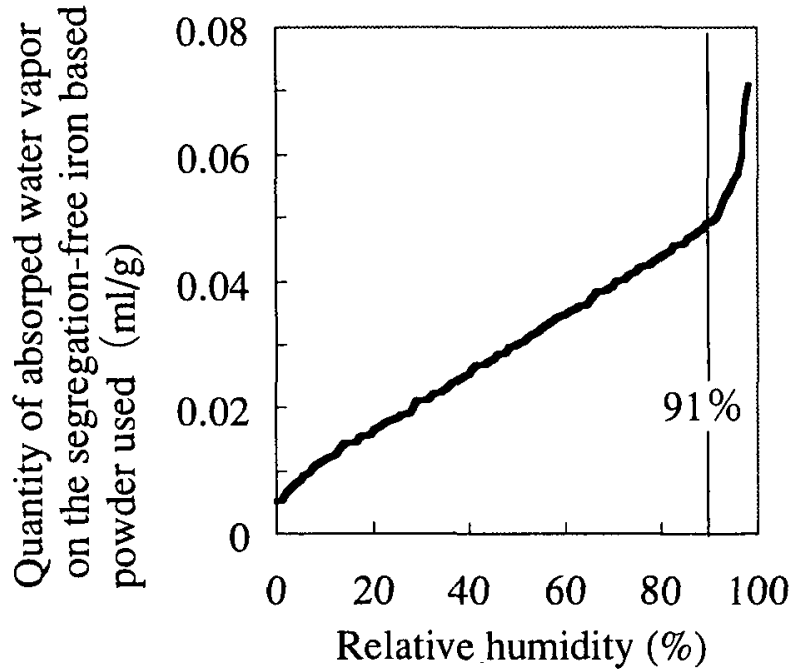

Fig.5 Absorption isotherm of water vapor on segregation-free iron based powder used. 
$10^{-8} \mathrm{~N} /$ 個であり，分子間力の計算結果とかなり良く一致した。 ワックス系偏析防止粉よりも流動性の優れるステアリン酸亜 鉛系偏析防止粉の付着力は $3.2 \times 10^{-8} \mathrm{~N} /$ 個と, ワックス系偏析 防止粉より低い值となった。これは，計算では潤滑郕のハマ カー係数は，種類に関わらず一定の值を使用しているが，実 際は潤滑唷により差があるためと考えられる。

これらの検討結果からバインダと潤滑剤間ならびに润滑剤 同土間の分子間力を低下させることが，偏析防止粉の流動性 改善に有効と考えられる。

\section{4 まとめ}

(1) ワックス系偏析防止粉における付着力の大きさを計算した 結果, 液架橋力 >分子間力 > 静電気力の順に小さくなる.

(2) ワックス系偏析防止粉の水蒸気の等温吸着線の測定結果か ら，相対湿度 $91 \%$ 以下では液架橋力は発生しないと考え られる。

(3) 鉄粉表面のバインダと潤滑剤間ならびに潤滑剤同士間に作 用する分子間力が流動性を支配すると考えられる。
文献

1）小倉: "原料粉末からみた自動車焼結部品の技術展望", 粉 体㧍よび粉末治金, 44(1997)470-474

2）峰岸, 牧野ら: "無偏析鉄粉 KIPクリーンミックス",川崎 製鉄技報, 24(1994)262.

3）石川, 小倉: “鉄粉および潤滑刻混合粉体層の流動性におよ ほす粉体特性の影響", 平成5年度粉末治金協会秋季大会講 演概要集, 64 .

4）伊ケ崎, 後藤："粉体の付着・凝集現象", 化技研ニュース, 15(1980) 1

5) 小口, 玉谷: "粉体の接触帯電とその応用 ", 応用物理, 52 (1980)674

6）福沢，木村：" 粉粒体の凝集性 (第 I 報) 凝集力の測定方法", 薬学雑誌, 92(1972)42.

7) 奥山，增田ら："2粒子間相互作用", 粉体工学会誌, 22(1985) 27.

8）増田："微粒子に働く最大静電気力の検討", 粉体工学会誌, 30(1993)713. 